\title{
Coauthorship and the Output of Academic Economists
}

\author{
Aidan Hollis* \\ Department of Economics, \\ University of Calgary
}

\begin{abstract}
This paper uses panel data on 339 economists to evaluate the relationship between coauthorship and output. It is shown that for a given individual, more coauthorship is associated with higher quality, greater length, and greater frequency of publications. However, the net relationship between coauthorship and output attributable to the individual is negative after discounting for the number of authors. The results of this paper suggest that universities and granting agencies which preferentially reward research collaboration may be undermining their goal of maximizing research output.
\end{abstract}

JEL: D2, J0

Key Words: teamwork, productivity, academic research, collaboration.

*2500 University Drive NW, Calgary, AB T2N 1N4 Canada. Email: ahollis@ucalgary.ca. Tel: 403-220-5861. Fax: 403282-5262. I am grateful to Chris Auld, Curtis Eaton, Daniel Hamermesh, David Laband, Frank Mixon, Steve Pischke, Aloysius Siow and Arthur Sweetman and two anonymous referees who offered many useful suggestions. I thank David Laband and Michael Piette for kindly providing data on the number of characters per page in different journals. 


\section{Introduction}

What is the relationship between coauthorship and the research productivity of academic economists? This is becoming an increasingly pertinent question, as the average number of authors per paper has risen to nearly two in economics, and $67 \%$ percent of papers have more than one author, paralleling a secular increase in the rate of coauthorship throughout academia. ${ }^{1}$ A variety of explanations has been proposed for this increase, such as increased specialization, greater pressure to publish, and even a decrease in the willingness of economists to assist each other without receiving authorship credit. At the same time, many granting agencies and universities have preferentially funded collaborative research in the belief that it may lead to new insights. ${ }^{2}$ However, whether collaboration enhances research output is a question suitable for empirical testing. This paper uses data on 5277 journal publications of 339 academic economists to explore the relationship between coauthorship and output. The data indicate clearly, and rather surprisingly, that coauthorship is negatively related to total research output.

There are many unknowns about the role of coauthorship in academia. First, what is the effect of collaboration on output? Does it increase the present productivity of the team members? Is there a learning effect so that current teamwork increases future productivity? Does collaboration lead to higher quality research, or more research, or both? Why do researchers engage in collaborative research? Should universities discount publications by the number of authors when deciding on salary and promotions? The panel data employed in this study enable us to begin to answer some of these questions.

Several previous studies have attempted to identify the relationship between coauthorship and academic productivity. McDowell and Smith (1992) use cross-sectional data on academics and regress the number of articles produced by an individual (with co-authored

\footnotetext{
${ }^{1}$ See McDowell and Melvin (1983) and Durden and Perri (1995) on economics. In other fields, the increase in coauthorship has also been noted. See Logan (1988) for sociology, Mendenhall and Higbee (1982) for psychology, and Endersby (1996) for several fields. The National Science Board (1998) report on Science and Technology shows a "pervasive trend towards greater scientific collaboration... [in] all article fields" (p. 5-43) with the proportion of articles involving authors from more than one institution increasing from 33\% to 50\% from 1981 to 1995.

${ }^{2}$ See Landry and Amara (1998).
} 
articles discounted by the number of authors) on the percentage co-authored and find no significant result. The absence of a significant relationship is not surprising in this context since the regression fails to condition on publishing ability, which would be problematic if individuals of innately high productivity tended to do more or less collaboration than less capable individuals. Landry, Traore and Godin (1996) use cross-sectional data on scientific researchers from several disciplines and find that higher rates of co-authorship are correlated with higher numbers of articles, but don't control for the researcher's discipline or quality of article, thus rendering the conclusions meaningless. Durden and Perri (1995) use time series data on annual economics publications over twenty-four years, and find that the number of total publications is positively related to the number of co-authored publications, a correlation which they claim shows collaboration "enhances productivity in total and per-capita article production." A more reasonable specification of their test would be to regress the total number of publications on the proportion co-authored. Using their data, I ran this regression and found no significant relationship. The time-series approach is however an inappropriate specification for the test proposed.

In this paper, by employing panel data on individuals, I control for underlying ability, and then identify how output changes in periods in which there is more or less coauthorship for an individual, an approach which allows for considerably more discrimination than cross-sectional or time-series studies. I begin by describing the data to be used in the study in the next section. I then examine how coauthorship affects quality, length, and frequency of publications, as well as a composite measure of output. In section 4 I examine some proposed explanations for the observed negative relationship between collaboration and output. Section 5 concludes.

\section{Data}

\subsection{Selection}

The data consists of the publication records of members of the American Economic Association in 1981 whose surnames begin with a, b, c, d, s, t, u or v and who had graduated from US and 
Canadian economics departments in the period 1965 to 1981. Not all individuals from these letter groups were used: common names such as "Smith" were excluded in order to minimize misattribution of articles. These letters were chosen to provide a distribution of names early and late in the alphabet. ${ }^{3} 78 \%$ of the sample graduated between 1969 and 1976 so that a full 20 years CV is available for those. I included only individuals with US or Canadian addresses who had publications listed in Econlit for at least 2 separate years between 1969 to 1997. ${ }^{4}$ Two individuals in the sample did not have PhDs. (One had a BA, one an MA.) I included only members of the AEA so that I could obtain data on graduation school, graduation date and current school of employment (as of 1981) from American Economic Association (1981). A summary of data with definitions, means and standard deviations is provided in Data Appendix (1). My sample is not perfectly representative of the profession: AEA members publish more on average than non-members, and I have included only individuals with at least two journal publications. There is however no reason for this selection bias to affect the key results of the paper in any meaningful way.

\subsection{Research}

I included only journal publications listed in Econlit because of the difficulty of evaluating the importance of other publications. For example, many collected volume articles are reprints, or are not peer reviewed. Sauer (1988) and Moore, Newman and Turnbull (1998), who attempt to identify the effect of non-journal publications on salary, find that the correlation is low and imprecise. Omitting non-journal publications is particularly undesirable in some fields, such as economic history, in which monographs are an important outlet for research. (My measure of output also fails to take into account differential teaching and administrative responsibilities across individuals and time. It was simply not possible to obtain information about those elements of output.) The best that can be said about using journal articles is that it is a proxy for

\footnotetext{
${ }^{3}$ The reason for this is that I was concerned that coauthorship might be preferred by individuals whose names came early in the alphabet. However, the regressions that I performed showed me that the effect of coauthorship on productivity of the group starting with $\mathrm{ABCD}$ was almost identical to that of the group starting with STUV.

${ }^{4}$ For some members of my sample, I had data only until 1996.
} 
research output. Each journal publication has a number of pages, a number of authors, and a quality index, which I discuss below.

My panel of data starts for each individual with his or her year of graduation and extends to the earlier of the year with the last observed publication or 1997. (For the few individuals in the data set who graduated before 1969, my panel begins at 1969.) I exclude years following the last observed publication because of the difficulty of drawing out any inferences about the observed lack of output from the unobserved level of coauthorship in those years. This leads to an unbalanced panel, where the frequency of observations by years since graduation is given by Figure 1. The set of journals indexed by Econlit has increased markedly since its inception in 1969, which adds another dimension in which the data changes over time.

\subsection{Coauthorship}

My core measure of the amount of coauthorship during a period is the arithmetic mean of the number of authors for all papers published by an individual during the period, and I call this variable "coauthorship". 5 In my data, the average level of coauthorship increases with the years since graduation, as shown in Figure 2. This measure is problematic in that I never observe the number of collaborators for research which does not result in journal articles. In addition, I do not observe the effort employed in any research, and this may vary systematically with the number of authors; nor do I observe the extent to which coauthorship was the product of close collaboration or simply specialization of duties.

The number of authors per article in my data equals the number of authors for all articles with fewer than five authors. For all articles with more than four authors, I assume four authors, since Econlit uses the abbreviation et al for articles with four or more authors. However, this

\footnotetext{
${ }^{5}$ A reasonable alternative measure of coauthorship allows for $n$ to be weighted in inverse proportion to the number of authors, so that sole authored papers are weighted more heavily than papers with four authors in determining the average amount of teamwork during the year. Such a measure would be $\frac{\text { articles }_{i t}}{\sum_{j} \frac{1}{n_{j}}}$ where articles $_{i t}$ is the number

of articles author $i$ publishes in period $t$, and $j$ indexes articles by an author within a time period. Results obtained using this alternative measure of coauthorship have similar coefficients as the regressions presented below.
} 
must be a small proportion of my data set, as is evident from Table 1, which shows the distribution of the number of authors per paper. ${ }^{6}$

\subsection{Pages}

The number of pages in articles was also derived from Econlit. The pages are adjusted to standard-length AER pages for all journals with known page length. ${ }^{7}$ Pages in the QJE, for example, have only $60 \%$ as many characters as pages in the AER and so they are adjusted accordingly. For all journals with unknown page length, I assume that they have the average number of characters per page, which is $80 \%$ of an AER page. Table 2 shows the frequencies of different length articles after standardizing page length.

\subsection{Quality}

Quality is the most difficult and contentious item to measure. To make some estimate of quality, I begin by assuming that the journal of publication is a good proxy of quality of the article. ${ }^{8}$ For this purpose, I used Laband and Piette's (1994) impact-weighted citation index (Table A2) for 130 journals. This index depends on the citations per character generated by articles in these journals, and weights the citations according to the citing journal. The quality measure I am using is thus equivalent to an expected impact-adjusted citations measure. For articles published in 1982 or before, I use the 1980 citations data. For articles published after 1982, I use the 1990 citations data. (The change in the citation index from the 1980 to the 1990 version causes a discrete decrease in my measure of average quality of the articles published. I therefore employ a dummy variable set to 1 for all years before 1983.) I modify this index further. For all journals listed in Laband and Piette whose citations per character index was below 1, I assume a value of 1 . I do not have a quality index for all journals, since my list of journal articles is in 413 journals, including 283 which are not listed by Laband and Piette. I assign unknown journals

\footnotetext{
${ }^{6}$ My data understate the number of articles with four or more authors, since Econlit lists only the first author for such articles. This means that authors late in the alphabet are likely to have few four-authored articles attributed to them.

${ }^{7}$ David Laband and Michael Piette kindly provided data on characters per page.

${ }^{8}$ It would have been slightly preferable (but much more difficult) to employ citations of each of the 5275 articles.
} 
indexed by Econlit a quality index of 0.8. Though these unknown journals are numerous, they constitute only $25 \%$ of the articles, $27 \%$ of total pages, and much less of the total qualityweighted output. ${ }^{9}$

However, it is not obvious that this is the "right" quality index. It implies that an article in the AER in the 1980s is worth approximately two articles in ReStud, seven in ReStat, or sixty in Journal of Development Economics. Many economists might prefer to have sixty lower ranked articles than one $A E R$. One way of examining the appropriateness of the index is to see how well it is correlated with the ranking of the school at which an individual is employed, which is discussed below in Section 2.7. I consider quality measures with the raw citation index raised to the exponents $1,0.75,0.50,0.30$, and 0.15 . I use these to construct measures of "lifetime" output. The measure which has the highest correlation with school quality is the preferred measure. The quality measure which is raised to the power 0.75 is slightly preferred over the others. ${ }^{10}$ I therefore use this measure principally in this study, although results for other exponents are not surprisingly quite similar. I call this quality measure quality 75 , and the number of articles of different qualities are tabulated in Table 3. (The quality index raised to the power 0.15 I label "quality15.”)

I also performed an analysis of a subset of the data (available from the author upon request) in which I regress the number of citations accruing to an article as a function of time since graduation and the number of authors, using a dummy variable to control for authors. The results are very similar to those reported below, giving some confidence that the results are robust.

\footnotetext{
${ }^{9}$ I also performed the set of regressions described below with the unknown journals omitted. The results (available upon request from the author) were very similar, so I am confident that these journal articles of unknown quality are not driving the observed relationships.

${ }^{10}$ Sauer (1988), who uses the quality adjustment based on Liebowitz and Palmer's (1984) impact-adjusted citation frequencies, finds that an exponent of 0.15 to 0.30 fits best with his salary regressions. I find that the exponent doesn't matter very much in my regressions.
} 


\subsection{Output}

I define output in a given period as $\pi_{i t}=\sum_{j} \frac{q_{j} p_{j}}{n_{j}}$ where $j$ indexes articles within a time period, $q$ is the quality index (e.g. quality75), $p$ is the number of AER length pages, and $n$ is the number of authors. If the quality index is quality75, I label this output measure output75. This measure implies that longer articles are more valuable pieces of research, which is reasonable if journal editors ration space in their journals in order to obtain the highest quality per page for a given number of pages. ${ }^{11}$ It also discounts the research by the number of authors, giving $1 / n$ credit to any single author, in order to account for the individual's contribution to the sum of research output.

The data here confirms some well known features of the research landscape. For example, the 36 authors at the top fourteen ranked schools in my data (my "Tier 1 schools") contributed $56 \%$ of the output (out of a total of 345 authors). Figure 3 graphs my total output measure added up over all individuals in my data set against years since graduation. ${ }^{12}$ There is a rapid increase in total output to two years after graduation, output peaks at slightly higher in the fourth year and then begins a steady decline. ${ }^{13}$ The change in output is due to fewer articles and lower quality of what is published, on average. Lower quality appears to be somewhat compensated by greater verbosity, as the average article length grows by about a page for every seven years since graduation.

\subsection{School Rankings}

I use a crude school ranking, where the top 13 schools from the ranking of Dusansky and Vernon (1998) plus Chicago are given value 3. The remaining top 50 schools are assigned value

\footnotetext{
${ }^{11}$ Piette and Ross (1992) and Hamermesh and Oster (1998) show that citations per article increase with article length, implying that editors ration space according to perceived scholarly value of the article. Nevertheless, it may be that two articles of 15 pages are perceived as being worth more than one of 30 pages. Discounting longer articles would however only strengthen the results I show below.

${ }^{12}$ I included only individuals who were in the sample for the full twenty years in this figure. Even so, Figure 3 understates the decline in publishing since there is significant growth in the number of journals during the period. See Oster and Hamermesh (1998) for more on this.

${ }^{13}$ This is consistent with the pattern described in Goodwin and Sauer (1995).
} 
2. All other US schools are given the value 1. I distribute foreign schools according to my estimate of their ranking. Some individuals as of 1981 had a non-academic affiliation. I give this a value of 0.5 . These values are used in identifying the quality of the school from which the person graduated, plus the school at which the person was employed in 1981. The frequencies in my data are tabulated in Table $4 .{ }^{14}$

\section{Results}

\subsection{The effect of coauthorship on quality, length, and frequency of publication}

The simple correlation between the number of authors and the quality of journal is weakly negative, given a random sample of articles. However, in my sample, this relationship becomes insignificant when I control for the number of pages and the number of years since the author of the article graduated. Of much more interest is how the quality of the journal changes by the number of authors when we control for the author. I show in Table 5 the results of a leastsquares dummy variable model with dummies for each author.

Columns (1) and (2) show the effects of coauthorship on journal quality. The dependent variables are my constructed quality measures quality 75 and quality 15 . The independent variables include dummy variables for the number of authors per paper, where the omitted category is of course single authored papers. It is evident that quality is positively related to the number of authors for a given author. The mean value of quality 75 for single authored articles is 7.619 (for quality 15, 1.316), so the "effect" of adding a second author is to increase average quality by about $15 \%$. This contrasts with the claim of Fox and Faver (1984) that collaboration may result in potential loss in research quality, but is consistent with Presser's (1980) study showing that collaboration is associated with fewer rejections in journal submissions, and Johnson's (1997) finding that, controlling for individual characteristics, co-authored papers tend to receive more citations. (Johnson is left puzzling over why economists do not collaborate more

\footnotetext{
${ }^{14}$ For the twenty individuals in my data without a known School of Employment in 1981, I assume in Tables 10-12 that they are at tier three schools.
} 
- a puzzle to which my research provides the solution.) Quality is also declining with years since graduation.

Column (3) of Table 5 shows the effect of coauthorship on article length, controlling for quality. The average single authored article is 9.5 pages and adding an extra author increases the length by about $20 \%$.

Coauthorship also appears to lead to more frequent publications. I estimate the effect of the average level of coauthorship on the number of articles a given researcher produces in a year. A problem that occurs here is that coauthorship is not observed in years with no output, which, as Table 6 shows, is very common. I generate estimated values of coauthorship for each individual for each year in which no output is observed as described in Data Appendix (2), and use these in my estimation. These estimated values are equal to the actual values for years with observed output. The nature of the data suggests that a panel Poisson regression is most suitable. The results of this regression are shown in Table 7, where the dependent variable is the number of articles in a given year for each individual. Column (1) of this table shows my preferred specification, and has as conditioning variables the graduation school and the lifetime average number of publications per year, as well as time variables. Column (2) adds the average level of prior coauthorship as a dependent variable. This shows the effect of previous collaboration on the number of articles published in a given year, and has a coefficient identical to that of the estimated level of current coauthorship. It implies that the more coauthorship done in the past (conditioning on current average coauthorship and the lifetime number of articles) the more prolific the author is likely to be today. It is possible that this is due to learning which occurs in the collaborative process, a topic to which I return in Section 4. In Column (3) I reestimate Column (1) with the restriction that only academics at Tier 2 schools are included. The coefficients on the estimated level of coauthorship imply that adding another author per year increases the number of articles published in that year by around $10 \%$ at the mean. 


\subsection{The relationship between coauthorship and output}

It is clear from the results in the previous section that academic teamwork has positive effects on quality, length and the number of articles. If this is what academics care about, then collaboration is privately rational. However, these effects do not necessarily indicate that output is increasing with co-authorship, since socially we care about the sum of research produced. ${ }^{15}$ This implies that in measuring the output of an individual, we should attribute only a share of coauthored articles. This section examines data by period to see how coauthorship is related to individuals' output per period, discounting articles by the number of authors.

The problem with the data is that in periods in which observed output is zero, it is possible that there was output, but not of the form of journal articles; or the output may be in the form of journal articles appearing in other years; or there may have been no input and no output. At the same time, we do not observe the amount of teamwork, if any, during those periods, and there is no reasonable way of inferring it from other data. Thus the data is truncated in an extreme and unusual fashion. While similar in some respects to the labor supply model in Heckman and MaCurdy (1980), the problem there is that when the wage falls below a certain level, no labor is supplied at all, and so no individual wage is observed: however, the average wage is known and provides some information concerning the individual wage. In my analysis, the explanatory variable of interest, average coauthorship during a period, is presumably not the major determinant of whether research occurs at all, but may influence how productive that research is, and there is no useful proxy for the unobserved amount of coauthorship. Thus it is not obvious how to interpret the truncation of my data.

To help illustrate this problem, consider Table 8 which shows the number of authors per paper $n$, the number of pages, quality, and a constructed measure of output for a sample individual over 6 years. In the years in which output is zero, no coauthorship is observed. It is

\footnotetext{
${ }^{15}$ It is possible that we don't really care about the sum of research produced. If society only cares about research output because of its value as a signal that the authors are competent to teach at the university level, then co-authored articles may not need to be discounted. In any case, it is clear that if we do not discount by the number of authors, output per individual increases with co-authorship.
} 
possible that the individual did some research with or without coauthors, but was unproductive; or that the individual did nothing whatsoever. One approach to dealing with this problem is to omit the zero years 1 and 3 altogether. However, this may be biased because a single-authored article appears as a large piece of output in a single year, whereas the same amount of effort may lead to several joint-authored pieces which could appear in different years. The individual above is just as "productive" according to my measure in years 5 and 6 cumulatively as in years 1 and 2 or 3 and 4 . A regression which simply omitted years 1 and 3 would find that output was negatively related to the number of authors. This would be a spurious conclusion, if indeed the individual was really working through years 1 and 3 , and it would be the correct conclusion if the individual was actually doing nothing in years 1 and 3 and working just as hard in years 5 and 6 as in years 2 and 4 .

The first step in identifying whether this is a problem is to examine whether higher levels of coauthorship leads to higher frequency of years with publications. As I showed above in Section 3.1, increasing collaboration appears to lead to higher numbers of publications. However, we are interested in whether it changes the probability that a given year will have publications. To do this, we regress the proportion of years with publications for each author on the lifetime average number of coauthors per paper and the lifetime number of papers for the individual. Results of this regression are presented in Table 9. The lifetime average number of coauthors per paper has no measurable effect on the proportion of years with publications for an author, whether or not we condition on the total lifetime number of papers. This suggests that the problem of zero years may not be very significant.

The most straightforward approach is therefore to ignore the zero year problem and to estimate a regression of the form

$$
y_{i t}=x_{i t} \beta+\mu_{i}+\varepsilon_{i t}
$$

where $y_{i t}$ is the output measure, $x_{i t}$ is the matrix of independent variables including the teamwork measure, $\beta$ is the vector of coefficients, $\mu_{i}$ is the fixed error component related to each individual, and $\varepsilon_{i t}$ is the white noise error component for each observation, and to treat 
zero years as missing. Because the variances of output and teamwork differ substantially between individuals, I employ feasible generalized least squares estimation to allow for heteroskedasticity.

Table 10 shows results from regressions of this sort. The first column shows results from the basic specification, in which the independent variables include coauthorship, years since graduation, and the indices of school quality. The second column includes an independent variable "Cumulative Output75" which sums lifetime output for the individual excluding output in the current period. Column three includes the mean number of authors on all papers published by the individual before the given year. The fourth and fifth columns replicate column three but with some restrictions of the data set: the fourth column includes only the first 15 years for each individual, since years with positive output grow sparser past that time; the fifth column includes individuals at tier one and two schools only, in order to exclude individuals whose output is infrequent. The mean value of the dependent variable for all years with positive output is shown at the bottom of each column. The implication of these regressions is that more coauthorship is expensive in terms of lost output: the range of coefficients on the coauthorship variable implies that adding an extra author reduces output by between $10 \%$ and $13 \% .^{16}$

A second approach to the zero year problem is to make the periodicity of the data less frequent. I lengthened the periods to three and five years. This ameliorates the zero year problem in two ways. First, it reduces the number of periods with zero output and unobserved teamwork; and second, it makes it less plausible that there is a bias in the estimate caused by co-authored research being spread across periods while a single-authored article must appear in only one period. The results for three-year periodicity are presented in columns 1-3 of Table 11 , and the results for 5-year periodicity are presented in columns 4-6. The coefficients of interest vary little with the periodicity of the data: in all cases the effect of adding an extra author at the mean is a reduction in output of between $7 \%$ and $11 \%$. In these longer periods, there are

\footnotetext{
${ }^{16}$ I also added in cubic and quartic forms of "years since graduation" in other regressions not shown here. They had little effect on the coefficients of interest.
} 
many fewer instances of periods with zero output, suggesting that the zero year problem is not what is driving the observed results. ${ }^{17}$

A third approach to removing the problem of truncation is to treat zero output as zero output, and to assume that the coauthorship for the zero years is the average of neighboring years. In the example above, that would result in a value of $n=1$ in years 1 and 3 . This approach seems quite strained for many of the individuals in the data set who have no measured output for years at a time. This method, with a large number of years with zero output (but imputed coauthorship), requires a panel Tobit regression in which I use the estimated level of coauthorship as an independent variable. Table 12 presents the results of panel Tobit regressions, duplicating Columns (1) to (3) of Table 10. The results continue to be consistent with those obtained in the other regressions, with the effect of adding an extra author at the mean being a reduction in output of about 15 to $20 \%$.

As a final test of the relationship between output and coauthorship, I obtained citation data for the years 1995 - 2000 on the publications of a subsample of 74 authors in my data set (those whose names begin with "A"). I then regressed the number of citations on the number of authors and a year index, controlling for author effects with a dummy variable for each author. The results are presented in Table 13, in which the first column makes use of my entire sample, and the second column omits one author (Orley Ashenfelter) one of whose articles was cited 276 times. As Table 13 shows, on average an extra coauthor increases the number of citations by approximately two (from the mean of six), and as Table 7 shows, a higher average rate of coauthorship increases the frequency of publishing articles. After taking these two effects into account, I calculate that at the mean, the number of citations per author declines by around $10 \%$ - $20 \%$ when the number of authors increases by one.

\footnotetext{
${ }^{17}$ A related approach to the problem of truncation is to use only groups of consecutive years in which output is positive. I estimated equations after eliminating all observations in which output is zero and all observations in which there were not at least three consecutive years of output. For the example in Table 8 above, that would have resulted in dropping years 1, 2 and 3 for the individual. I also estimated equations restricting my sample to observations which came from periods having at least eight consecutive years of output. In these regressions, the effect of adding an extra author at the mean is to reduce output by between $9 \%$ and $11 \%$.
} 
The fact that all of the methods I used to deal with zero-output problem resulted in a single conclusion ${ }^{18}$ - that coauthorship is negatively related to the current output of academic economists - demands an explanation.

\section{Is coauthorship unproductive?}

The results presented above show that for most economists, while collaboration appears to increase the frequency, quality and length of publications, it is also correlated with lower total output per author after discounting for the number of authors. Why would such a relationship exist? (And why do economists persist in working together, if indeed there is a negative effect on output per author?) It is helpful to distinguish between three types of explanations for the apparent negative relationship between output and collaboration. First, there is the possibility of systematic mismeasurement. The second type of explanation assumes teamwork is chosen for some reason other than its effect on output, which may lead to unproductive collaboration. The third class of explanation assumes that teamwork is endogenously determined and that the observed relationship is the result of the individual choosing to be sole author of the "easiest" and most productive projects.

\subsection{Mismeasurement}

The simplest explanation for the apparent negative relationship between teamwork and output is that I have been using the wrong measure of productivity. For example, economists may have a higher valuation of quality than I use in these regressions, and so, based on a very extreme quality slope, coauthoring is productive. This explanation is improbable, since the quality measure I use already has a very steep slope, valuing a top journal publication at a large multiple of intermediate field journals. The results hold even when using Laband and Piette's impact adjusted citation index as the quality measure. The regressions presented in Table 13, using citation analysis of individual papers, also correspond with the previous results.

\footnotetext{
${ }^{18}$ The estimated reduction in output from teamwork in these regressions is comparable to the implied reduction in output generated by adding up the separate effects of teamwork on quality, length, and frequency of publications estimated in Section 3.1.
} 
A second measurement issue is that I use journal quality as a proxy for article quality, which would be problematic if it is biased against coauthorship. It is possible that sole authors aim at higher journals, and that coauthors sometimes compromise on journal quality in order to achieve publication. ${ }^{19}$ This explanation is supported by studies which show that coauthored articles, controlling for journal quality, tend to be more heavily cited; and by evidence that acceptance rates are higher for coauthored than for sole authored submissions (Laband and Tollison, 2000). Again, however, it is difficult to believe that this is a significant factor in the observed relationship.

\subsection{Teamwork Determined Exogenously}

Suppose that we assume that coauthorship occurs exogenously, or for some reason which is not correlated with productivity. Then the data imply that it has a negative effect on productivity. Is this plausible, and why might it have such an effect? Teamwork may harm productivity for a number of reasons. A natural possibility is free-riding. Alchian and Demsetz (1972) identified this problem in teamwork, as well a natural way of avoiding it. However, teamwork between academic economists usually involves excellent opportunities for observing the input of fellow team members, so it is difficult to believe that this is a major problem.

A second possibility is that teams may simply be an inefficient method of production because of duplication of effort or coordination costs. Most economists have stories of coauthors who had different ideas about how to write a paper and ended up continually rewriting each other's work. One way of identifying this problem is to look for papers which are listed in Econlit as being in multiple categories, since then teamwork would more likely be between individuals who had different skill sets and hence would be less likely to duplicate each others' efforts. I attempted to control for this in my data by creating a dummy for all publications which were listed as being in multiple fields. This provides a very crude measure of whether papers are in different fields. I crossed the dummy with the teamwork variable to see whether teamwork was more or less productive when it was employed in multiple-field publications. The

\footnotetext{
${ }^{19}$ This explanation was suggested to me by Daniel Hamermesh.
} 
interacted terms, however, were insignificantly different from each other, which is perhaps not surprising given the crudity of the measure.

John McDowell and Michael Melvin find in a 1983 cross-sectional analysis that the probability of coauthorship of a given author is higher, the more rapidly knowledge depreciates in the field, implying that there is a productivity motivation for teamwork. Barnett, Ault, and Kaserman (1988) similarly find that articles which include both theory and empirical components tend more frequently to be co-authored, suggesting that there may be a productive division of labor involved. ${ }^{20}$

Even if teamwork is sometimes productive, the data indicate that, for a given individual, it is associated with lower output on average. Thus it is puzzling that it continues to occur with such frequency. I suggest here a number of possible explanations.

First, it may be that economists do not discount publications by $1 / n$. This may occur because of a perception that others - granting agencies, universities, and colleagues - do not discount by $1 / n$. Sauer (1988) shows that $1 / n$ discounting is not rejected by data on salaries and publications, but Moore, Newman and Turnbull (1995) find in comparable salary-based data that departments do not discount joint authored papers significantly. ${ }^{21}$ Liebowitz and Palmer (1983), McDowell and Smith (1992) and Schinski, Kugler and Wick (1998) report the result of surveys that in determining salaries and promotions, universities do not typically fully discount coauthored work by the number of authors. ${ }^{22}$ Granting agencies and universities often encourage collaboration, apparently in the belief that such teamwork is likely to result in better research. ${ }^{23}$ Still assuming that teamwork is determined exogenously, the results presented

\footnotetext{
${ }^{20}$ While I have found that teamwork is unproductive on average for academic economists, my conclusions do not necessarily clash with theirs. If economists are collaborating for reasons other than productivity, the smaller the productivity cost of teamwork, the more likely coauthoring will be.

${ }^{21}$ One of the problems faced by studies such as Sauer (1988) and Moore, Newman and Turnbull (1995) is that their data is cross-sectional but the individuals they are examining are at different stages of their careers. This is problematic since the propensity to coauthor articles increases substantially with academic seniority, as I show in Figure 2.

${ }^{22}$ Outside of economics, Long and McGinnis (1982) claim that "colleagues do not appear to discount for multiple authorships." (p. 381)

${ }^{23}$ This raises an interesting side question: why would schools and granting agencies choose to reward collaborative teamwork preferentially? One possible answer to this puzzle is to consider Holmstrom's (1982) explanation of the role of the principal in the firm as a budget-breaker. Given a partnership, agents cannot be induced to undertake the optimal
} 
above suggest that teamwork leads not only to better research, but also a decrease in qualityadjusted total output. If indeed universities and granting agencies do not discount by $1 / n$, there is a potentially important policy issue: are they contributing to excessive, inefficient teamwork ? $^{24}$ Petry and Kerr (1981) find that coauthorship appears to rise when individual scholars perceive that the rewards to publication are not discounted by the number of authors.

A second possible reason for "inefficient" teamwork is that economists enjoy working together, rather than singly, and there is a consumption benefit from teamwork which compensates for the reduced output. Of course, I cannot observe this with the data at hand. However, survey studies of academic collaboration suggest that this may be important (Fox and Faver 1984). Hamermesh and Oster (1998) conclude from examining the difference in citations accruing to papers with physically close and distant coauthors that economists often choose distant coauthorship for the consumption benefits of working with a friend. In a recent survey by Melin (2000), about $25 \%$ of researchers cited "social reasons" when asked the reasons for collaboration.

A third possible reason is that while teamwork reduces current output, there may be a learning effect so that it increases future output. There is little evidence in support of this hypothesis. I introduce the average amount of coauthorship of all prior periods into the regressions summarized in Tables 7 and 10 - 12. The coefficient on it is inconsistent across the different specifications, suggesting that if there is a learning effect, it is small. Some authors have suggested that "mentoring" may be a significant reason for teamwork, but the evidence presented here and in Mixon (1997) does not support this hypothesis. ${ }^{25}$

effort; therefore either monitoring or some kind of budget breaking principal is required. Such budget breaking might take the form of penalty or bonus. If one were to make an argument that schools are encouraging joint work, then the reason for excess recognition of joint work could be in order to budget break. By over-rewarding joint work, the school could increase decrease free-riding and increase effort in collaborative research to closer to the optimal amount.

24 The Social Sciences and Humanities Research Council of Canada (1996) promotes "International Research Linkages to encourage collaboration between Canadian and foreign scholars or teams of scholars on joint research or research communication projects in the humanities and the social sciences," because collaboration is "vital to the development of innovative, world-class research." As a result of this, they have a special program to promote collaborative research.

25 The Social Sciences and Humanities Research Council of Canada (1996) has identified encouraging mentoring as one of its priorities in its strategic plan: "To ensure the ongoing dynamism and excellence of the research endeavour, it is 
A fourth reason which has been suggested for academic coauthorship is to reduce risk (Laband and Piette, 1995). There are a number of reasons why teamwork, since it increases the number of projects an academic can work on, might reduce risk. Academics may be uncertain of the quality of any given project, or of their own ability to complete the research agenda, or of the prospects of publishing a given piece. By sharing authorship in several articles, academics are able to insure against the risk of publishing nothing. However, given that we observe low levels of coauthoring near the beginning of careers of untenured faculty members, and higher levels later for individuals who have job security, this explanation is unconvincing.

A fifth possible reason for unproductive collaboration is that academics themselves are unaware of the efficiency effects. Certainly the size of the productivity effect of teamwork is surprising to most colleagues to whom I have presented this result. A common response is to suggest that academics may be keeping their best ideas to themselves, and sharing the less interesting ideas. This explanation, alas, fails since the data on quality shows that for a given individual, coauthorship is positively correlated with article quality. If anything, the better ideas are the ones being shared, which should not be surprising, since a coauthor would only accept to work on a project if the idea was "better" than the other projects available to her. The apparent ignorance about the relationship between academic teamwork and research output may perhaps stem from the observed secular increase in academic coauthorship, which seems to suggest that it is in fact efficient. (It could, of course, simply be the case that teamwork is becoming less costly over time. My data set is ill-equipped to test this hypothesis, since all the authors are from one 15-year cohort. ${ }^{26}$ Or perhaps there has been an increase in the level of research expectations, which has made the consumption benefits from teamwork companionship - more valuable than before.)

important to include the perspectives of young scholars and to nurture their talents through close working ties to senior researchers with breadth and depth of experience."

${ }^{26}$ I tried testing for this but found no significant relationship. 


\subsection{Teamwork Chosen Endogenously}

A different approach to explaining the observed negative relationship between output and teamwork is to recognize that teamwork may be chosen endogenously, that is to say, that the amount of coauthorship depends on the opportunity set facing the individual. An academic would choose from this opportunity set projects with varying levels of inherent quality and difficulty. The opportunity set would consist of projects of which the individual had conceived, and of projects offered to the individual as a coauthor. In such circumstances, we might expect that really good ideas requiring no specialization outside the author's would be sole authored. Only ideas which required the skills of other researchers would be coauthored. That is to say, the "easy" papers would be sole-authored, which would result in a positive correlation between sole-authorship and high output. Thus the observed negative relationship between coauthorship and output does not prove that coauthorship is unproductive. Indeed, it is possible that there is too little co-authorship: in order not to have to share the credit for papers which are relatively good but relative easy, individuals may decide to sole-author research which could be more efficiently done with a co-author. ${ }^{27}$

In a model of research production which accounts for the endogeneity of teamwork, we would expect that the researcher would attempt to maximize utility. The variables in the utility function might include research output, income, social activities, and others. Universities typically do not fully discount by the number of coauthors in promotion, tenure and salary decisions, which would tend to lead to excess teamwork; similarly, social activities are enhanced by teamwork. Thus even when we view teamwork as endogenously chosen, we are likely to get more of it than would be optimal strictly from the perspective of maximizing research output. In sum, while the data cannot discriminate between endogenous and exogenous teamwork explanations, it seems plausible that a combination of the two may be driving the observed result. That is to say, co-authorship may be chosen partly for reasons which are endogenous to output - i.e. some ideas are hard to do for the individual - and partly for reasons which have

\footnotetext{
${ }^{27}$ I thank Curtis Eaton for pointing out to me how the endogeneity of teamwork leads to this ambiguity.
} 
nothing to do with output - i.e. to increase pay or to obtain the consumption benefits of collaboration.

\section{Discussion}

Using panel data on 339 economists, this paper has shown that output is negatively related to coauthorship: the more an individual economist co-authors, the lower the research output attributable to that individual. More collaboration appears to lead to more frequent, longer, and better publications, but when the publications are discounted by the number of authors, the relationship between research output and teamwork becomes negative. Reasonable estimates of the size of this relationship are that, at the mean, adding one more author is associated with a per capita reduction in output of between $7 \%$ and $20 \%$. The use of panel data is revealing here; previous studies which have used cross-section or time series data have found a spurious positive relationship between output and academic collaboration. However, the results are weakened by the inability to observe the "true" amount of coauthorship or the set of opportunities facing the author.

If we start out with an underlying model of academics who wish to maximize utility, and include in our utility function only research output, then we should expect to find that at the margin research productivity will be equal for sole-authored and joint-authored projects. However, it seems reasonable to include salary and "companionship" in the typical academic's utility function, so we would expect to find that academics do not choose the level of coauthorship that maximizes output. Indeed, if it is the case that for most academics, more companionship would increase utility, ceteris paribus, then we should also expect that the marginal productivity of teamwork will be below the marginal productivity of sole authorship. This difference would only be increased if it is indeed the case that academics are over-rewarded for team research. Once considered from this perspective, the negative relationship between coauthorship and 
output is not surprising. What is puzzling is the persistence of universities and granting agencies in encouraging collaboration. If teamwork is an efficient method of obtaining research output, then academics will naturally choose it, and given a consumption benefit from teamwork, will choose too much of it even without any financial encouragement.

While this study uses data on economists only, a reasonable presumption is that at least some of the results carry over to other fields as well, though this remains to be investigated. More generally, it raises the question of whether we would observe similar results outside academia. Teamwork is common to many activities and we observe teamwork which is similar in character to academic collaboration in many other industries: research, creative work such as advertising, and indeed almost all white collar industries. It would be interesting to try to replicate this study in a non-academic industry. 


\section{Data Appendix}

(1) Summary Description of Variables

\begin{tabular}{|c|c|c|c|c|}
\hline Name & Definition & Mean & $\begin{array}{l}\text { Standard } \\
\text { Deviation }\end{array}$ & \# Obs. \\
\hline Lifetime Articles & Lifetime number of articles per author & 15.56 & 17.62 & 339 \\
\hline $\begin{array}{l}\text { Average Lifetime } \\
\text { Articles }\end{array}$ & $\begin{array}{l}\text { Lifetime number of articles per author } \\
\text { divided by the number of years the author is } \\
\text { present in the data. }\end{array}$ & 0.787 & .694 & 339 \\
\hline $\begin{array}{l}\text { Articles per } \\
\text { period }\end{array}$ & Number of articles per author per year. & 0.792 & 1.208 & 6656 \\
\hline Grad School & School of graduation index (higher is better) & 2.168 & .712 & 339 \\
\hline $\mathbf{n}$ & The number of coauthors of a paper. & 1.716 & .714 & 5277 \\
\hline $\begin{array}{l}\text { Lifetime } \\
\text { Coauthorship }\end{array}$ & The lifetime mean of $n$ by author & 1.678 & 0.424 & 339 \\
\hline Coauthorship & The mean of $n$ in a period, by author. & 1.701 & 0.656 & 3040 \\
\hline $\begin{array}{l}\text { Previous } \\
\text { Coauthorship }\end{array}$ & $\begin{array}{l}\text { The mean of } \mathrm{n} \text { for all previous periods for an } \\
\text { individual author. }\end{array}$ & 1.523 & 1.390 & 6089 \\
\hline $\begin{array}{l}\text { Estimated } \\
\text { Coauthorship }\end{array}$ & $\begin{array}{l}\text { Estimated level of coauthorship. See data } \\
\text { appendix (2) }\end{array}$ & 1.650 & 0.627 & 6656 \\
\hline Pages & $\begin{array}{l}\text { The number of AER-length pages in an } \\
\text { article. }\end{array}$ & 10.258 & 7.146 & 5277 \\
\hline $\begin{array}{l}\text { Cumulative } \\
\text { Output75 }\end{array}$ & $\begin{array}{l}\text { The cumulative sum of output } 75 \text { for all } \\
\text { previous periods for an author. }\end{array}$ & 496.209 & 1337.221 & 6656 \\
\hline Pre83 Dummy & Dummy = 1 for all years before 1983. & 0.200 & 0.400 & 6656 \\
\hline quality15 & $\begin{array}{l}\text { Laband \& Piette (1994) impact adjusted } \\
\text { citation index raised to the power } 0.15\end{array}$ & 1.307 & 0.356 & 5277 \\
\hline quality 75 & $\begin{array}{l}\text { Laband \& Piette (1994) impact adjusted } \\
\text { citation index raised to the power } 0.75\end{array}$ & 7.327 & 9.166 & 5277 \\
\hline $\begin{array}{l}\text { School of } \\
\text { Employment }\end{array}$ & $\begin{array}{l}\text { Index of school quality in } 1981 \text { (higher is } \\
\text { better) }\end{array}$ & 1.487 & 0.708 & 319 \\
\hline $\begin{array}{l}\text { Years since } \\
\text { graduation }\end{array}$ & Years since graduation & 10.470 & 6.896 & 6656 \\
\hline Output75 & $\begin{array}{l}\text { Output per author per period (including } \\
\text { years with zero output) }\end{array}$ & 40.002 & 124.805 & 6656 \\
\hline
\end{tabular}

For all measures which are periodic, the means and standard deviations in the above table assume annual measures. There are 339 authors, 5277 articles, and 6656 author-years, in 3040 of which there was positive output. 


\section{(2) Generating estimated values of teamwork for years with no publications.}

To generate estimated values of teamwork for years with no publications, I constructed average levels of observed teamwork for each five year period and each ten year period, and each lifetime. For years with no output, the estimated number of authors is the average number of authors in that five-year period; if the average number of authors in the five year period is missing, then I use the ten-year average; and if that is missing, then I use the lifetime average. 


\section{References}

Alchian, A. and H. Demsetz, 1972, Production, Information Costs and Economic Organization, American Economic Review 62, 777-795.

American Economic Association, 1981, Biographical Listing of Members, American Economic Review 71(6), 31-455.

Barnett, A., R. Ault, and D. Kaserman, 1988, The Rising Incidence of Co-Authorship in Economics: Further Evidence, Review of Economics and Statistics 70(3), 539-543.

Durden, G. and T. Perri, 1995, Coauthorship and Publication Efficiency, Atlantic Economic Journal 23(1), 69-76.

Dusansky, R. and C. Vernon, 1998, Rankings of U.S. Economics Departments, Journal of Economic Perspectives 12(1), 157-170.

Endersby, J.W., 1996, Collaborative Research in the Social Sciences: Multiple Authorship and Publication Credit, Social Science Quarterly 77, 375-392.

Fox, M.F. and C.A. Faver, 1984, Independence and Collaboration in Research: The Motivations and Costs of Collaboration, Journal of Higher Education 55(3), 347-359.

Goodwin, T. and R. Sauer, 1995, Life Cycle Productivity in Academic Research: Evidence from Cumulative Publication Histories of Academic Economists, Southern Economic Journal 61(3), 728-743.

Hamermesh, D. and S. Oster, 1998, Tools or Toys? The Impact of High Technology on Scholarly Productivity, NBER Working Paper 6761. 
Heckman, J. and T. Macurdy, 1980, A Life Cycle Model of Female Labour Supply, Review of Economic Studies 47(1), 47-74.

Holmstrom, B., 1982, Moral Hazard in Teams, Bell Journal of Economics 13(2), 324-340.

Johnson, D., 1997, Getting Noticed in Economics: The Determinants of Academic Citations, The American Economist 41(1), 43- 52.

Laband, D. and M. Piette, 1994, The Relative Impacts of Economics Journals: 1970 - 1990, Journal of Economic Literature 32, 640-666.

Laband, D. and M. Piette, 1995, Team Production in Economics: Division of Labor or Mentoring? Labour Economics 2, 33-40

Laband, D. and R.D. Tollison, 2000, Intellectual Collaboration, Journal of Political Economy 108(3), 632-662.

Landry, R. and N. Amara, 1998, The Impact of Transaction Costs on the Institutional Structuration of Collaborative Academic Research, Research Policy 27, 901-913.

Landry, R., N. Traore, and B. Godin, 1996, An Econometric Analysis of the Effect of Collaboration on Academic Research Productivity, Higher Education 323, 283-301.

Liebowitz, S. and J. Palmer, 1983, Assessing Assessments of the Relative Quality of Economics Departments, Quarterly Review of Economics and Business 28(2), 88-113.

Liebowitz, S. and J. Palmer, 1984, Assessing the Relative Impacts of Economics Journals, Journal of Economic Literature 22(1), 77-88. 
Logan, J., 1988, Producing Sociology: Time Trends in Authorship of Journal Articles, 19751986, American Sociologist 19(2), 167-180.

Long, J.S. and R. McGinnis, 1982, On Adjusting Productivity Measures for Multiple Authorship, Scientometrics 4(5), 379-387.

McDowell, J. and M. Melvin, 1983, The Determinants of Co-Authorship: An Analysis of the Economics Literature, Review of Economics and Statistics 65(1), 155-160.

McDowell, J. and J. Smith, 1992, The Effect of Gender-sorting on Propensity to Coauthor: Implications for Academic Promotion, Economic Inquiry 30, 68-82.

Melin, G., 2000, Pragmatism and Self-Organization: Research Collaboration on the Individual Level, Research Policy 20, 31-40.

Mendenhall, M., and K. Higbee, 1982, Recent Trends in Multiple Authorship in Psychology, Psychological Reports 51(3) 1019 - 1022.

Mixon, F.G., 1997, Team Production in Economics: A Comment and Extension, Labour Economics 4, 185-191.

Moore, W., R. Newman and G. Turnbull, 1995, Pay and Performance: Search, Matching, and Implicit Contracts in Academic Labor Markets, Mimeo, Louisiana State University.

Moore, W., R. Newman and G. Turnbull, 1998, Do Academic Salaries Decline with Seniority? Journal of Labor Economics 16(2), 352-366.

National Science Board, 1998, Science \& Engineering Indicators, (National Science Foundation, Arlington, VA (NSB 98-1)). 
Oster, S. and D. Hamermesh, 1998, Aging and Productivity among Economists: Note, Review of Economics and Statistics 80(1), 154-156.

Petry, G. and H. Kerr, 1981, The Rising Incidence of Coauthorship as a Function of Institutional Reward Systems, Journal of Financial Education 9, 78-84.

Piette, M. and K. Ross, 1992, A Study of the Publication of Scholarly Output in Economics, Eastern Economic Journal 18, 429-436.

Presser, S., 1980, Collaboration and the Quality of Research, Social Studies of Science 10, 95-101.

Sauer, R.D., 1988, Estimates of the Returns to Quality and Coauthorship in Economic Academia, Journal of Political Economy 96(4), 855-866.

Schinski, M., A. Kugler, and W. Wick, 1998, Perceptions of the Academic Finance Profession Regarding Publishing and the Allocation of Credit in Coauthorship Situations, Financial Practice and Education 8(1), 60-68.

Social Sciences and Humanities Research Council of Canada, 1996, Striking the Balance: SSHRC's Five-Year Strategic Plan (Ottawa). 
TABLE 1

Distribution of the Number of Authors per Paper

\begin{tabular}{lrr}
\hline $\mathbf{n}$ & Freq. & Percent \\
\hline 1 & 2244 & 42.52 \\
2 & 2349 & 44.51 \\
3 & 622 & 11.79 \\
4 & 62 & 1.17 \\
\hline Total & $\mathbf{5 2 7 7}$ & $\mathbf{1 0 0 . 0 0}$
\end{tabular}




\section{TABLE 2}

Distribution of Page Lengths

\begin{tabular}{lrr}
\hline pages & Freq. & Percent \\
\hline $0-3$ & 561 & 10.63 \\
$3-6$ & 1016 & 19.25 \\
$6-10$ & 1353 & 25.64 \\
$10-20$ & 1965 & 37.24 \\
$20+$ & 382 & 7.24 \\
\hline Total & $\mathbf{5 2 7 7}$ & $\mathbf{1 0 0 . 0 0}$
\end{tabular}




\section{TABLE 3}

Distribution of Papers by Quality

\begin{tabular}{lrr}
\hline quality75 & Freq. & Percent \\
\hline 0.84 & 1377 & 26.09 \\
$1-3$ & 1472 & 27.89 \\
$3-5$ & 294 & 5.57 \\
$5-8$ & 548 & 10.38 \\
$8-12$ & 326 & 6.18 \\
$12-20$ & 555 & 10.52 \\
$20-31$ & 705 & 13.36 \\
\hline Total & $\mathbf{5 2 7 7}$ & $\mathbf{1 0 0 . 0 0}$
\end{tabular}


TABLE 4

Distribution of Authors by School of Employment and PhD

\begin{tabular}{rrrrr}
\hline & \multicolumn{2}{c}{ School of Employment } & \multicolumn{2}{c}{ Grad School } \\
rank & Freq. & Percent & Freq. & Percent \\
\hline .5 & 13 & 4.08 & 0 & 0.00 \\
1 & 179 & 56.11 & 62 & 18.29 \\
2 & 92 & 28.84 & 158 & 46.61 \\
3 & 35 & 10.97 & 119 & 35.10 \\
\hline Total & 319 & $\mathbf{1 0 0 . 0 0}$ & 339 & $\mathbf{1 0 0 . 0 0}$
\end{tabular}




\section{TABLE 5}

Quality and Page Length as a Function of the Number of Authors

\begin{tabular}{|c|c|c|c|}
\hline & $\begin{array}{c}\text { (1) } \\
\text { Quality75 }\end{array}$ & $\begin{array}{c}\text { (2) } \\
\text { Quality15 }\end{array}$ & $\begin{array}{c}(3) \\
\text { Pages }\end{array}$ \\
\hline 2 Authors & $\begin{array}{l}1.192^{* *} \\
(0.272)\end{array}$ & $\begin{array}{l}0.048^{* *} \\
(0.010)\end{array}$ & $\begin{array}{c}1.846^{* *} \\
(0.229)\end{array}$ \\
\hline 3 Authors & $\begin{array}{l}1.427^{\star \star} \\
(0.408)\end{array}$ & $\begin{array}{c}0.058^{\star *} \\
(0.015)\end{array}$ & $\begin{array}{l}2.750^{* *} \\
(0.343)\end{array}$ \\
\hline 4+ Authors & $\begin{array}{c}1.276 \\
(1.072)\end{array}$ & $\begin{array}{c}0.032 \\
(0.040)\end{array}$ & $\begin{array}{l}2.592^{* *} \\
(0.905)\end{array}$ \\
\hline Years since Graduation & $\begin{array}{l}-0.337^{\star} \\
(0.149)\end{array}$ & $\begin{array}{l}-0.010^{*} \\
(0.006)\end{array}$ & $\begin{array}{l}-0.054 \\
(0.126)\end{array}$ \\
\hline (Years since Graduation) $^{2}$ & $\begin{array}{c}0.009 \\
(0.012)\end{array}$ & $\begin{array}{c}0.000 \\
(0.000)\end{array}$ & $\begin{array}{c}0.019^{*} \\
(0.010)\end{array}$ \\
\hline (Years since Graduation) $^{3}$ & $\begin{array}{c}0.000 \\
(0.000)\end{array}$ & $\begin{array}{c}0.000 \\
(0.000)\end{array}$ & $\begin{array}{l}-0.001^{*} \\
(0.000)\end{array}$ \\
\hline Pre83 Dummy & $\begin{array}{l}1.553^{\star *} \\
(0.452)\end{array}$ & $\begin{array}{l}0.093^{\star *} \\
(0.017)\end{array}$ & $\begin{array}{c}0.554 \\
(0.382)\end{array}$ \\
\hline Pages & $\begin{array}{l}-0.129^{\star \star} \\
(0.017)\end{array}$ & $\begin{array}{l}-0.004^{\star *} \\
(0.001)\end{array}$ & \\
\hline Quality75 & & & $\begin{array}{l}-0.092^{\star *} \\
(0.012)\end{array}$ \\
\hline Constant & $\begin{array}{c}10.225^{\star \star} \\
(0.729)\end{array}$ & $\begin{array}{c}1.395^{\star *} \\
(0.027)\end{array}$ & $\begin{array}{l}8.402^{* *} \\
(0.617)\end{array}$ \\
\hline Observations & 5277 & 5277 & 5277 \\
\hline
\end{tabular}

Standard errors in parentheses

* significant at $5 \%$ level; ** significant at $1 \%$ level 


\section{TABLE 6}

Articles per author per year

\begin{tabular}{crr}
\hline Articles & Frequency & Percent \\
\hline 0 & 3616 & 54.33 \\
1 & 1804 & 27.10 \\
2 & 734 & 11.03 \\
3 & 269 & 4.04 \\
4 & 110 & 1.65 \\
5 & 54 & 0.81 \\
6 & 36 & 0.54 \\
7 & 15 & 0.23 \\
8 & 9 & 0.14 \\
9 & 3 & 0.05 \\
11 & 4 & 0.06 \\
12 & 2 & 0.03 \\
\hline Total & 6656 & 100.00
\end{tabular}


TABLE 7

The Effect of Coauthorship on the Number of Articles per Author per Year

\begin{tabular}{|c|c|c|c|}
\hline & (1) & (2) & $\begin{array}{c}\text { (3) } \\
\text { Tier } 2 \text { Employers only }\end{array}$ \\
\hline Estimated Coauthorship & $\begin{array}{l}0.094^{* *} \\
(0.023)\end{array}$ & $\begin{array}{l}0.081^{* *} \\
(0.024)\end{array}$ & $\begin{array}{l}0.095^{\star \star} \\
(0.040)\end{array}$ \\
\hline Years since Graduation & $\begin{array}{l}0.054^{\star *} \\
(0.007)\end{array}$ & $\begin{array}{l}-0.013 \\
(0.008)\end{array}$ & $\begin{array}{l}0.040^{\star \star} \\
(0.012)\end{array}$ \\
\hline (Years since Graduation) $^{2}$ & $\begin{array}{l}-0.002^{* *} \\
(0.000)\end{array}$ & $\begin{array}{l}0.000 \\
(0.000)\end{array}$ & $\begin{array}{l}-0.001^{*} \\
(0.000)\end{array}$ \\
\hline Tier 1 Grad School & $\begin{array}{c}0.020 \\
(0.047)\end{array}$ & $\begin{array}{l}0.061 \\
(0.048)\end{array}$ & $\begin{array}{l}-0.005 \\
(0.100)\end{array}$ \\
\hline Tier 2 Grad School & $\begin{array}{r}0.075^{*} \\
(0.043)\end{array}$ & $\begin{array}{l}0.095^{*} \\
(0.044)\end{array}$ & $\begin{array}{l}0.054 \\
(0.098)\end{array}$ \\
\hline Tier 1 Employer & $\begin{array}{l}0.008 \\
(0.050)\end{array}$ & $\begin{array}{l}0.017 \\
(0.050)\end{array}$ & \\
\hline Tier 2 Employer & $\begin{array}{l}0.188^{* *} \\
(0.033)\end{array}$ & $\begin{array}{l}0.158^{\star \star} \\
(0.034)\end{array}$ & \\
\hline Non-Academic Employer & $\begin{array}{l}-0.021 \\
(0.084)\end{array}$ & $\begin{array}{l}0.002 \\
(0.086)\end{array}$ & \\
\hline Average Lifetime Articles & $\begin{array}{l}0.559^{* *} \\
(0.011)\end{array}$ & $\begin{array}{l}0.510^{* *} \\
(0.013)\end{array}$ & $\begin{array}{l}0.666^{\star *} \\
(0.027)\end{array}$ \\
\hline Previous Coauthorship & & $\begin{array}{l}0.084^{* *} \\
(0.011)\end{array}$ & \\
\hline Constant & $\begin{array}{l}-1.329^{\star \star} \\
(0.062)\end{array}$ & $\begin{array}{l}-0.958^{\star \star} \\
(0.067)\end{array}$ & $\begin{array}{l}-1.219^{\star \star} \\
(0.127)\end{array}$ \\
\hline Observations & 6656 & 6089 & 1928 \\
\hline Number of authors & 339 & 339 & 92 \\
\hline
\end{tabular}

Standard errors in parentheses

${ }^{*}$ significant at $5 \%$ level; ${ }^{* *}$ significant at $1 \%$ level 
TABLE 8

Sample Data

\begin{tabular}{ccccc}
\hline Year & $\mathbf{n}$ & Pages & Quality & Output \\
\hline 1 & - & 0 & & 0 \\
2 & 1 & 10 & 1 & 10 \\
3 & - & 0 & & 0 \\
4 & 1 & 15 & 0.67 & 10 \\
5 & 2 & 10 & 1 & 5 \\
6 & 2 & 20 & 0.5 & 5 \\
\hline
\end{tabular}




\section{TABLE 9}

The Effect of Lifetime Coauthorship on the Proportion of Years with Publications

\begin{tabular}{lcc}
\hline & $(\mathbf{1})$ & $(\mathbf{2})$ \\
\hline Lifetime Coauthorship & 0.041 & -0.005 \\
Tier 1 Grad School & $(0.029)$ & $0.020)$ \\
& 0.044 & 0.039 \\
Tier 2 Grad School & $(0.037)$ & $(0.025)$ \\
Tier 1 Employer & 0.047 & 0.037 \\
& $(0.035)$ & $(0.023)$ \\
Tier 2 Employer & $0.129^{* \star}$ & 0.007 \\
Non-Academic Employer & $(0.044)$ & $(0.030)$ \\
Lifetime Articles & $0.129^{* *}$ & $0.051^{* *}$ \\
Constant & $(0.029)$ & $(0.020)$ \\
& -0.073 & -0.028 \\
& $(0.065)$ & $(0.043)$ \\
Observations & & $0.011^{* *}$ \\
R-squared & & $(0.001)$ \\
\hline
\end{tabular}

Standard errors in parentheses

${ }^{*}$ significant at $5 \%$ level; ${ }^{*}$ significant at $1 \%$ level 
TABLE 10

Effect of Teamwork on Output (Annual Data; Omitting Years with Zero Output)

\begin{tabular}{|c|c|c|c|c|c|}
\hline & $\begin{array}{c}\text { (1) } \\
\text { All Data }\end{array}$ & $\begin{array}{c}\text { (2) } \\
\text { All Data }\end{array}$ & $\begin{array}{c}\text { (3) } \\
\text { All Data }\end{array}$ & $\begin{array}{c}(4) \\
\text { First } 15 \text { years } \\
\text { after graduation }\end{array}$ & $\begin{array}{c}(5) \\
\text { Excluding Tier } \\
3 \text { Schools }\end{array}$ \\
\hline Coauthorship & $\begin{array}{c}-10.064^{* *} \\
(1.250)\end{array}$ & $\begin{array}{l}-9.356^{\star *} \\
(1.392)\end{array}$ & $\begin{array}{l}-8.801^{* *} \\
(1.400)\end{array}$ & $\begin{array}{c}-13.294^{* *} \\
(1.506)\end{array}$ & $\begin{array}{c}-15.639^{* *} \\
(2.774)\end{array}$ \\
\hline Cumulative Output75 & & $\begin{array}{l}0.036^{* *} \\
(0.003)\end{array}$ & $\begin{array}{l}0.032^{* *} \\
(0.003)\end{array}$ & $\begin{array}{l}0.065^{\star *} \\
(0.006)\end{array}$ & $\begin{array}{l}0.032^{* *} \\
(0.004)\end{array}$ \\
\hline Previous Coauthorship & & & $\begin{array}{r}1.497^{\star} \\
(0.875)\end{array}$ & $\begin{array}{l}-1.475 \\
(1.141)\end{array}$ & $\begin{array}{l}5.376^{\star \star} \\
(1.547)\end{array}$ \\
\hline Years since Graduation & $\begin{array}{l}-1.163^{*} \\
(0.582)\end{array}$ & $\begin{array}{l}-3.332^{* *} \\
(0.665)\end{array}$ & $\begin{array}{l}-5.181^{* *} \\
(0.731)\end{array}$ & $\begin{array}{l}-5.027^{\star *} \\
(1.365)\end{array}$ & $\begin{array}{l}-6.921^{* *} \\
(1.431)\end{array}$ \\
\hline $\begin{array}{l}\text { (Years since } \\
\text { Graduation) }^{2}\end{array}$ & $\begin{array}{l}-0.001 \\
(0.019)\end{array}$ & $\begin{array}{r}0.043^{*} \\
(0.023)\end{array}$ & $\begin{array}{l}0.091^{* *} \\
(0.024)\end{array}$ & $\begin{array}{c}0.034 \\
(0.079)\end{array}$ & $\begin{array}{c}0.062 \\
(0.047)\end{array}$ \\
\hline Tier 1 Grad School & $\begin{array}{l}24.315^{\star *} \\
(3.005)\end{array}$ & $\begin{array}{l}15.663^{\star *} \\
(2.885)\end{array}$ & $\begin{array}{l}15.191^{\star \star} \\
(2.998)\end{array}$ & $\begin{array}{l}11.554^{\star *} \\
(3.067)\end{array}$ & $\begin{array}{l}20.889^{* *} \\
(7.185)\end{array}$ \\
\hline Tier 2 Grad School & $\begin{array}{l}5.513^{* *} \\
(1.946)\end{array}$ & $\begin{array}{l}3.685 \\
(2.386)\end{array}$ & $\begin{array}{c}3.848 \\
(2.418)\end{array}$ & $\begin{array}{l}-3.423 \\
(2.272)\end{array}$ & $\begin{array}{r}11.876^{*} \\
(6.899)\end{array}$ \\
\hline Tier 1 Employer & $\begin{array}{l}137.518^{\star \star} \\
(10.466)\end{array}$ & $\begin{array}{l}75.572^{\star *} \\
(9.372)\end{array}$ & $\begin{array}{l}78.613^{\star *} \\
(9.443)\end{array}$ & $\begin{array}{c}77.483^{\star \star} \\
(11.569)\end{array}$ & $\begin{array}{l}91.461^{* *} \\
(10.219)\end{array}$ \\
\hline Tier 2 Employer & $\begin{array}{l}20.778^{* *} \\
(2.326)\end{array}$ & $\begin{array}{l}11.946^{\star *} \\
(2.421)\end{array}$ & $\begin{array}{l}14.316^{\star *} \\
(2.307)\end{array}$ & $\begin{array}{l}12.542^{\star *} \\
(2.865)\end{array}$ & $\begin{array}{l}33.569^{\star *} \\
(4.383)\end{array}$ \\
\hline $\begin{array}{l}\text { Non-Academic } \\
\text { Employer }\end{array}$ & $\begin{array}{l}32.083^{\star *} \\
(11.081)\end{array}$ & $\begin{array}{c}17.760^{*} \\
(8.737)\end{array}$ & $\begin{array}{c}20.376^{\star *} \\
(7.582)\end{array}$ & $\begin{array}{l}20.368^{*} \\
(10.775)\end{array}$ & \\
\hline Pre 83 Dummy & $\begin{array}{l}9.714^{\star *} \\
(2.865)\end{array}$ & $\begin{array}{l}7.430^{\star *} \\
(3.038)\end{array}$ & $\begin{array}{l}2.946 \\
(2.937)\end{array}$ & $\begin{array}{l}7.035^{\star \star} \\
(2.778)\end{array}$ & $\begin{array}{l}-7.737 \\
(5.212)\end{array}$ \\
\hline Constant & $\begin{array}{l}46.080^{* *} \\
(5.163)\end{array}$ & $\begin{array}{l}60.874^{\star *} \\
(5.726)\end{array}$ & $\begin{array}{c}73.977^{\star *} \\
(6.165)\end{array}$ & $\begin{array}{l}84.390^{\star *} \\
(6.875)\end{array}$ & $\begin{array}{l}89.755^{\star *} \\
(13.356)\end{array}$ \\
\hline Observations & 3040 & 3040 & 2932 & 1983 & 1558 \\
\hline Number of authors & 339 & 339 & 339 & 334 & 147 \\
\hline Mean Output75 & 87.584 & 87.584 & 87.584 & 100.418 & 124.375 \\
\hline
\end{tabular}

Standard errors in parentheses

* significant at $5 \%$ level; ** significant at $1 \%$ level 


\section{TABLE 11}

Effect of Teamwork on Output ( 3 \& 5 year periods; Omitting Periods with Zero Output)

\begin{tabular}{|c|c|c|c|c|c|c|}
\hline & \multicolumn{3}{|c|}{3 Year Periods } & \multicolumn{3}{|c|}{5 Year Periods } \\
\hline & (1) & (2) & (3) & (4) & (5) & (6) \\
\hline Coauthorship & $\begin{array}{c}-16.952^{\star *} \\
(2.361)\end{array}$ & $\begin{array}{c}-16.558^{* *} \\
(2.531)\end{array}$ & $\begin{array}{c}-16.338^{\star *} \\
(2.625)\end{array}$ & $\begin{array}{c}-19.333^{* *} \\
(3.425)\end{array}$ & $\begin{array}{c}-15.504^{* *} \\
(4.519)\end{array}$ & $\begin{array}{c}-14.887^{\star \star} \\
(4.707)\end{array}$ \\
\hline $\begin{array}{l}\text { Cumulative } \\
\text { Output75 }\end{array}$ & & $\begin{array}{l}0.086^{\star *} \\
(0.008)\end{array}$ & $\begin{array}{l}0.084^{* *} \\
(0.008)\end{array}$ & & $\begin{array}{l}0.093^{\star \star} \\
(0.012)\end{array}$ & $\begin{array}{l}0.108^{* *} \\
(0.012)\end{array}$ \\
\hline $\begin{array}{l}\text { Previous } \\
\text { Coauthorship }\end{array}$ & & & $\begin{array}{c}1.557 \\
(1.542)\end{array}$ & & & $\begin{array}{l}-1.652 \\
(2.506)\end{array}$ \\
\hline $\begin{array}{l}\text { Years since } \\
\text { Graduation }\end{array}$ & $\begin{array}{l}11.543^{\star *} \\
(2.700)\end{array}$ & $\begin{array}{l}-2.353 \\
(3.496)\end{array}$ & $\begin{array}{l}-4.005 \\
(3.612)\end{array}$ & $\begin{array}{c}24.370^{* *} \\
(6.324)\end{array}$ & $\begin{array}{l}10.790 \\
(8.919)\end{array}$ & $\begin{array}{l}2.051 \\
(9.890)\end{array}$ \\
\hline $\begin{array}{l}\text { (Years since } \\
\text { Graduation) }^{2}\end{array}$ & $\begin{array}{l}-1.367^{\star *} \\
(0.277)\end{array}$ & $\begin{array}{l}-0.768^{*} \\
(0.365)\end{array}$ & $\begin{array}{l}-0.643^{*} \\
(0.376)\end{array}$ & $\begin{array}{l}-4.854^{* *} \\
(1.055)\end{array}$ & $\begin{array}{l}-5.891^{\star *} \\
(1.470)\end{array}$ & $\begin{array}{l}-4.248^{\star *} \\
(1.643)\end{array}$ \\
\hline $\begin{array}{l}\text { Tier } 1 \text { Grad } \\
\text { School }\end{array}$ & $\begin{array}{l}58.995^{\star \star} \\
(5.250)\end{array}$ & $\begin{array}{l}42.881^{* *} \\
(4.949)\end{array}$ & $\begin{array}{l}41.378^{* *} \\
(5.139)\end{array}$ & $\begin{array}{l}75.085^{\star \star} \\
(8.044)\end{array}$ & $\begin{array}{c}67.765^{\star \star} \\
(7.606)\end{array}$ & $\begin{array}{l}60.447^{\star *} \\
(8.145)\end{array}$ \\
\hline $\begin{array}{l}\text { Tier } 2 \text { Grad } \\
\text { School }\end{array}$ & $\begin{array}{r}6.217^{*} \\
(3.250)\end{array}$ & $\begin{array}{c}2.076 \\
(3.900)\end{array}$ & $\begin{array}{c}0.551 \\
(4.171)\end{array}$ & $\begin{array}{c}1.935 \\
(4.207)\end{array}$ & $\begin{array}{l}-0.444 \\
(6.208)\end{array}$ & $\begin{array}{l}-0.387 \\
(6.296)\end{array}$ \\
\hline Tier 1 Employer & $\begin{array}{l}275.406^{* *} \\
(25.079)\end{array}$ & $\begin{array}{l}140.985^{\star *} \\
(21.410)\end{array}$ & $\begin{array}{l}144.204^{* *} \\
(21.887)\end{array}$ & $\begin{array}{l}402.253^{* *} \\
(42.520)\end{array}$ & $\begin{array}{l}232.551^{* *} \\
(35.581)\end{array}$ & $\begin{array}{c}224.883^{\star *} \\
(36.036)\end{array}$ \\
\hline Tier 2 Employer & $\begin{array}{l}41.610^{* *} \\
(4.622)\end{array}$ & $\begin{array}{l}17.608^{\star *} \\
(4.999)\end{array}$ & $\begin{array}{l}17.228^{\star *} \\
(5.144)\end{array}$ & $\begin{array}{c}68.377^{* *} \\
(7.381)\end{array}$ & $\begin{array}{l}65.361^{* *} \\
(6.760)\end{array}$ & $\begin{array}{l}54.542^{\star *} \\
(7.273)\end{array}$ \\
\hline $\begin{array}{l}\text { Non-Academic } \\
\text { Employer }\end{array}$ & $\begin{array}{l}38.908^{*} \\
(22.662)\end{array}$ & $\begin{array}{c}11.021 \\
(18.173)\end{array}$ & $\begin{array}{c}11.572 \\
(18.009)\end{array}$ & $\begin{array}{c}53.490 \\
(32.861)\end{array}$ & $\begin{array}{c}30.755 \\
(26.588)\end{array}$ & $\begin{array}{c}29.643 \\
(26.405)\end{array}$ \\
\hline Pre 83 Dummy & $\begin{array}{l}70.423^{* *} \\
(4.759)\end{array}$ & $\begin{array}{l}70.366^{* *} \\
(5.205)\end{array}$ & $\begin{array}{l}70.319^{* *} \\
(5.376)\end{array}$ & $\begin{array}{c}134.993^{* *} \\
(7.665)\end{array}$ & $\begin{array}{c}121.353^{* *} \\
(9.382)\end{array}$ & $\begin{array}{c}128.608^{* *} \\
(9.598)\end{array}$ \\
\hline Constant & $\begin{array}{c}28.855^{\star \star} \\
(6.763)\end{array}$ & $\begin{array}{l}73.821^{* *} \\
(9.685)\end{array}$ & $\begin{array}{l}76.003^{\star *} \\
(10.003)\end{array}$ & $\begin{array}{c}40.256^{* *} \\
(9.867)\end{array}$ & $\begin{array}{l}77.621^{* *} \\
(13.117)\end{array}$ & $\begin{array}{l}87.392^{* *} \\
(16.343)\end{array}$ \\
\hline Observations & 1731 & 1731 & 1720 & 1275 & 1275 & 1269 \\
\hline Number of authors & 339 & 339 & 339 & 339 & 339 & 339 \\
\hline Mean Output75 & 153.816 & 153.816 & 153.816 & 208.830 & 208.830 & 208.830 \\
\hline
\end{tabular}

Standard errors in parentheses

* significant at $5 \%$ level; ** significant at $1 \%$ level 


\section{TABLE 12}

Effect of Teamwork on Output (Annual; Tobit; Generated Values of Teamwork for Years with Zero Output)

\begin{tabular}{|c|c|c|c|}
\hline & (1) & (2) & (3) \\
\hline Estimated Coauthorship & $\begin{array}{l}-7.558 \\
(4.290)\end{array}$ & $\begin{array}{l}-7.851 \\
(4.253)\end{array}$ & $\begin{array}{l}-6.357 \\
(4.256)\end{array}$ \\
\hline Cumulative Output75 & & $\begin{array}{l}-.015^{\star \star} \\
(.003)\end{array}$ & $\begin{array}{l}-.019^{\star \star} \\
(.003)\end{array}$ \\
\hline Previous Coauthorship & & & $\begin{array}{c}10.636^{*} \\
(3.232)\end{array}$ \\
\hline Years since Graduation & $\begin{array}{l}18.151^{* *} \\
(1.309)\end{array}$ & $\begin{array}{l}19.113^{\star *} \\
(1.321)\end{array}$ & $\begin{array}{l}14.147^{\star *} \\
(1.638)\end{array}$ \\
\hline (Years since Graduation) $^{2}$ & $\begin{array}{l}-.306^{\star \star} \\
(.047)\end{array}$ & $\begin{array}{l}-.303^{\star *} \\
(.047)\end{array}$ & $\begin{array}{l}-.172^{*} \\
(.054)\end{array}$ \\
\hline Tier 1 Grad School & $\begin{array}{l}46.062^{\star *} \\
(14.667)\end{array}$ & $\begin{array}{l}58.388^{\star *} \\
(14.959)\end{array}$ & $\begin{array}{l}71.514^{* *} \\
(14.170)\end{array}$ \\
\hline Tier 2 Grad School & $\begin{array}{c}23.161 \\
(14.110)\end{array}$ & $\begin{array}{l}35.991^{* *} \\
(14.744)\end{array}$ & $\begin{array}{c}41.756^{* *} \\
(11.767)\end{array}$ \\
\hline Tier 1 Employer & $\begin{array}{l}156.934^{\star *} \\
(15.284)\end{array}$ & $\begin{array}{l}199.200^{* *} \\
(16.600)\end{array}$ & $\begin{array}{c}199.811^{\star *} \\
(16.612)\end{array}$ \\
\hline Tier 2 Employer & $\begin{array}{l}38.474^{* *} \\
(12.978)\end{array}$ & $\begin{array}{l}47.220^{* *} \\
(12.644)\end{array}$ & $\begin{array}{c}56.005^{\star *} \\
(10.550)\end{array}$ \\
\hline Non-Academic Employer & $\begin{array}{c}34.897 \\
(23.882)\end{array}$ & $\begin{array}{c}39.885 \\
(23.857)\end{array}$ & $\begin{array}{c}54.503^{*} \\
(20.854)\end{array}$ \\
\hline Pre 83 Dummy & $\begin{array}{c}273.606^{\star *} \\
(7.064)\end{array}$ & $\begin{array}{c}273.525^{\star *} \\
(7.070)\end{array}$ & $\begin{array}{c}257.898^{* *} \\
(7.361)\end{array}$ \\
\hline Constant & $\begin{array}{c}-312.976^{\star *} \\
(15.915)\end{array}$ & $\begin{array}{c}-330.938^{\star *} \\
(16.433)\end{array}$ & $\begin{array}{c}-318.114^{\star \star} \\
(16.421)\end{array}$ \\
\hline Observations & 6656 & 6656 & 6089 \\
\hline Number of authors & 339 & 339 & 339 \\
\hline Mean Output75 & 40.002 & 40.002 & 40.002 \\
\hline
\end{tabular}

Standard errors in parentheses

${ }^{*}$ significant at $5 \%$ level; ** significant at $1 \%$ level 


\section{TABLE 13}

\section{Effect of Teamwork on Citations per Article}

(1)

(2)

(omitting Ashenfelter)

\begin{tabular}{lcc}
\hline Authors per Article & $1.945^{* *}$ & $1.633^{* *}$ \\
& $(0.708)$ & $(0.582)$ \\
Year -1960 & $-1.782^{* *}$ & .510 \\
& $(0.618)$ & $(.556)$ \\
$($ Year -1960) & & -0.017 \\
& $0.026^{*}$ & $(0.011)$ \\
Constant & $(0.013)$ & 1.293 \\
& $30.018^{* *}$ & $(6.665)$ \\
\hline Observations & $(7.322)$ & 1052 \\
Number of authors & 1108 & 73 \\
Mean citations & 74 & 5.436 \\
Mean authors per article & 6.146 & 1.775 \\
\hline
\end{tabular}

Standard errors in parentheses

* significant at $5 \%$ level; ** significant at $1 \%$ level 
Figure 1

Histogram of Observations by Years since Graduation

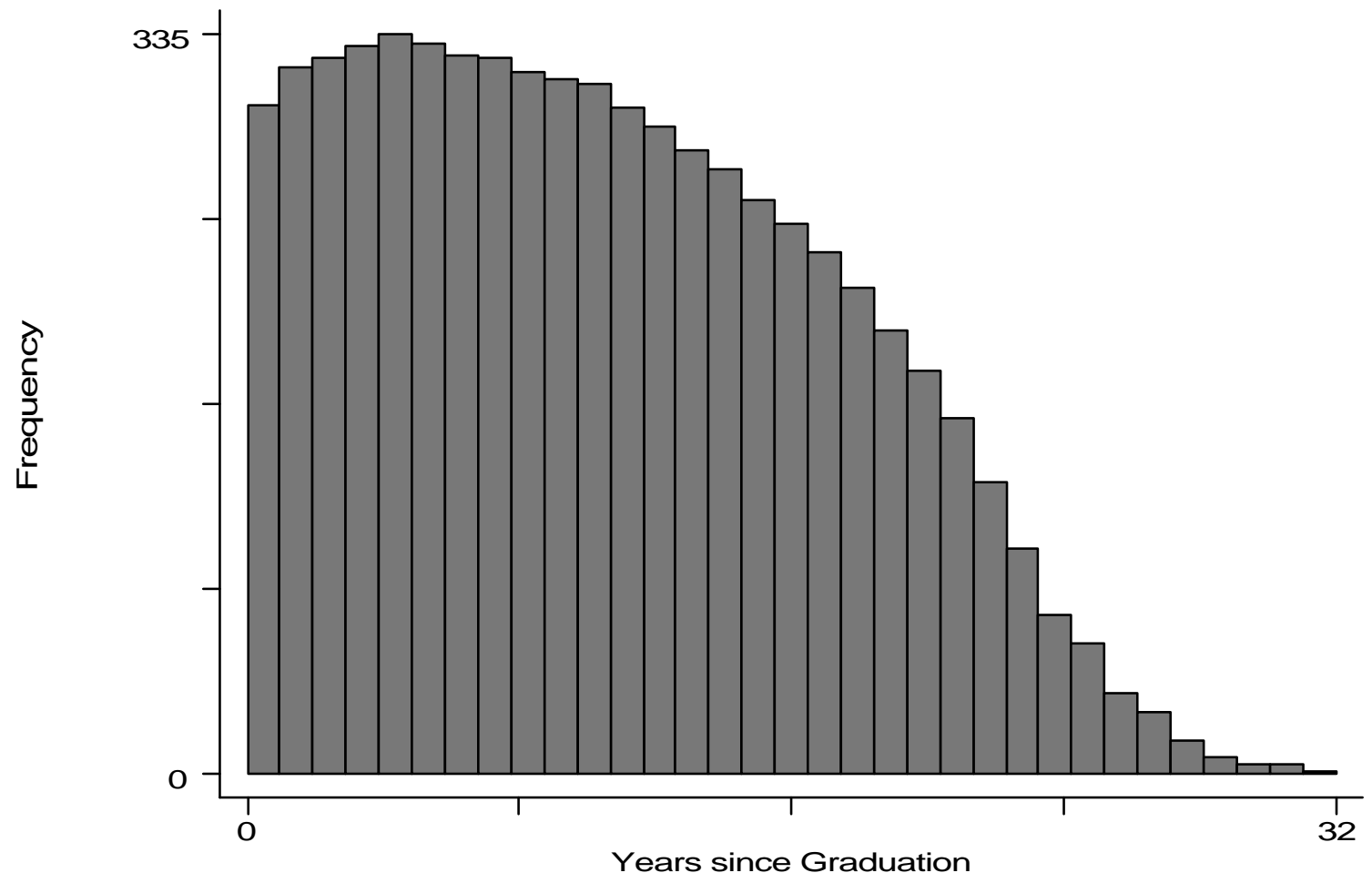


Figure 2

Average number of authors by year since graduation

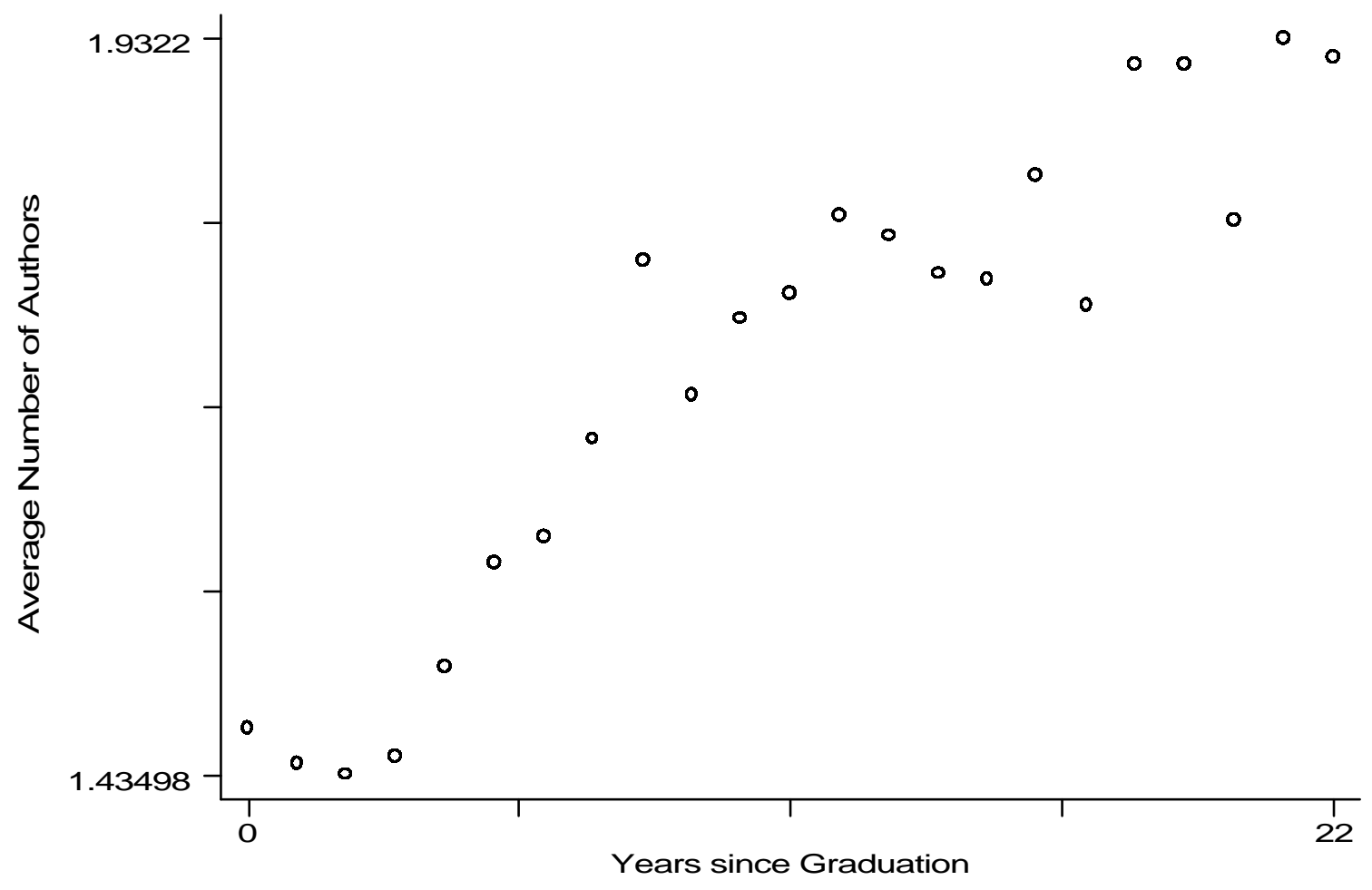


There are relatively few observations for years beyond 22 years after graduation and so I exclude them, though the trend continues up. 
Figure 3

Total Output per Year as a function of years since graduation

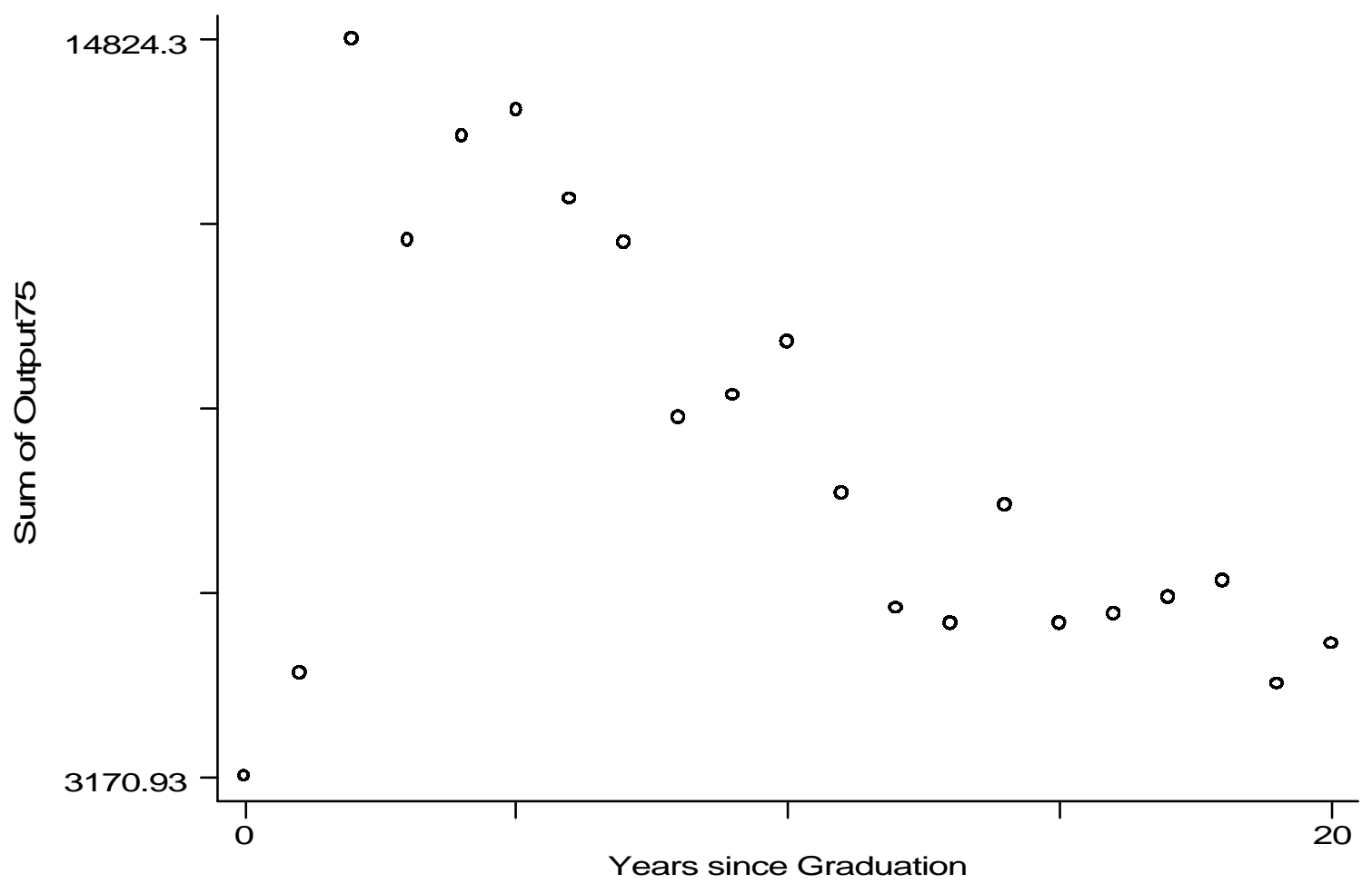


The vertical axis represents the sum of output for all members of the data set who graduated between 1969 and 1977 for the first 20 years since their graduation. 